\title{
Benefits of the National Special Programme for Food Security in Niger State, Nigeria
}

\author{
Atteh, A.P. \\ Department of Agricultural Economics and Extension, \\ Federal University of Lafia, Nasarawa State, Nigeria
}

\begin{abstract}
The study examined the benefits of the National Special Programme for Food Security (NSPFS) in Niger State, Nigeria. A total of 180 respondents were selected using multistage sampling technique. The project sites were chosen purposively comprising of all the nine sites of NSPFS in Niger State, namely; Nassarawa, Batavovogi, Lenfa-Bororo, Gidan-Mangoro, Garam, Mankangara, Lioji, Kaboji and Shambo. The respondents were selected proportionately based on each site's activities. Data collection lasted from 15th February, 2013 to 31st August, 2013. Data were analyzed using descriptive statistics such as percentages and means, frequency distribution and t-test. The results of the analysis showed an indication that the NSPFS performed well. The beneficiaries were satisfied with the implementation of the following components: agro-input support, extension and financial services. NSPFS significantly improved the crop output of beneficiaries as compared to non-beneficiaries. The benefits that accrued to the beneficiaries of the programme ranges from credit grant to farmers to provision of storage facilities which translated into increased outputs. The following recommendations were made based on the major findings of the study. The NSPFS should focus more attention on mechanization, storage facilities, agroprocessing, marketing, small scale irrigation, and infrastructure, because it will help the benefitting famers to actualize their pre-determined goals, it will also improve their well-being.
\end{abstract}

Keywords: Food, Security, Performance, Special Programme, Food Security

DOI: $10.7176 / \mathrm{JBAH} / 11-6-02$

Publication date:March $31^{\text {st }} 2021$

\section{Introduction}

Food security at household, village, national and international levels require the availability of adequate quantity and quality of locally-grown agricultural products; accessibility of supplies for urban and land-remote areas, appreciation of the close link between nutrition and health for work and enjoyment; avoidance of undue risk through livelihood vulnerability, hazard and shock in reserves. Maziya-Dixton, Akinyele, Oguntona, Nokoe, Sanusi and Harris, (2004) defined food security as the access at all times by the people, either through own production or through purchase of enough food for active, healthy life. Food security exists when every person has physical and economic access at all times to healthy, nutritious food in sufficient quantity to cover the need of their daily ration and food preferences, in order to live a healthy, and active life (Sengooba, 1994). In a situation where this does not occur, we have food insecurity. It may be chronic or transitory.

In chronic food insecurity, there is continuous inadequate diet and nutrition caused by the household's inability to acquire food. It manifests in the form of persistent inability to either buy food or produce food on their own, on the other hand, transitory food insecurity results from a temporary decline in household access to food due mainly to instability in food price, production, household income or a combination of these factors in a critical situation. In Nigeria, two-thirds of the population lives below the poverty line and household food security is inadequate (Vision, 2010). Nigerians suffer both income and food poverty and poor access to the means of supporting rural development among other causative factors (World Health Organization (WHO, 2004). Consequently, food security which goes with food self-sufficiency and sustainability is still elusive (Nworgu, 2006). This is because, the agricultural sector has not been able to deal effectively with the problem of food security for the Nigerian people when viewed from the stand points of the nutritional status of Nigerians, household food security and food prices (Vision, 2010).

Based on the 1996 World Food Summit, Nigeria is one of the 82 Low-Income Food Deficit Countries (LIFDCs) who requested for assistance under the Food and Agriculture Organization (FAO), to introduce National Special Programme for Food Security (NSPFS), with the aim to ensuring sufficient food supply in Nigeria among others. This involved a tripartite participatory review of the government's request, which include of the stakeholders, namely, FAO, the Government (Federal and State) and the beneficiary communities held in Nigeria in March 1998. In furtherance to the cause, an advance allocation was approved under the Tripartite Communities Participation (TCP) to support the finalization of the formulation of the pilot phase of the NSPFS in Kano State, Nigeria. It was in this context, that the Federal and State Governments with the technical support of the FAO became interested in extending the application of the programme for food security to all states in Nigeria. This programme aimed to achieve rapid increase in productivity and food production on an economically sustainable basis, emphasizing the use of tested technologies and grass-root participation (Mero, 2001). 


\section{The Concept of Food Security}

Food security is a flexible concept as reflected in the attempts to define it in a research work and policy usage. A decade ago, there were about 200 definitions in published writings for it (Maxwell \& Smith, 1992). Whenever, the concept is introduced in the title of a study or its objectives, it is necessary to look closely to establish the explicit or implied definition (Maxwell, 1996). The continuing evolution of food security as an operational concept in public policy has reflected the wider recognition of the complexities of the technical and policy issued involved. The most recent careful redefinition of food security is that, negotiated in the process of international consultation leading to the World Food Summit (WFS) in November 1996. The contrasting definitions of food security adopted in 1974 and 1996, along with those in official Food Agriculture Organization (FAO) and World Bank document of mid 1980s, are set out below with each substantive change in definition.

Food security as a concept originated only in the mid 1970s, in the discussions of international food problem at a time of global food crisis. The initial focus of attention was primarily on food supply problems of assuring the availability and to some degree the price stability of basic foodstuffs at the international and national level like ours. In the World Food Conference of 1974, a new set of institutional arrangement covering information, resources for promoting food security and forum for dialogue on policy issues, Overseas Development Institute (ODI, 1997). The issues of famine, hunger and food crisis were also being extensively examined, following the event of mid 1970s. The outcome was a redefinition of food security, which recognized that the behaviour of potentially vulnerable and affected people was a critical aspect. Food security is a concept that has evolved considerably over time. In the last decade, attention has been focused on means to eliminate insecurity and hunger world-wide. Four definitions of food security have been used by international organizations congress and United States Agency for International Development (USAID, 1999). This makes people to have access to food at all times, to have enough for an active, healthy life. "All people at all-time have both physical and economic access to the basic food they need." "Accesses by all people at all times have access to sufficient food to meet their dietary need for a productive and healthy life".

Food availability is achieved when sufficient quantities of appropriate, necessary types of food are consistently available to all individuals within a country or are within reasonable proximity to then or are within their reach. Such food can be supplied through household production other domestic outputs, commercial imports of food assistance, constraints to food availability include: inappropriate agriculture knowledge, technologies, and practices; inappropriate economic policies, including: pricing, marketing, tax and tariff policies; lack of foreign exchange; inadequate agricultural inputs; non-existent or ineffective private sector; population growth rates that offset increased production or imports; marketing and transportation systems which inhibit the cost-effective movement of food from source to need, inability to predict, assess and cope with emergency situations which interrupt food supplies; natural resource, climatic, and in most cases in Africa we have disease constraints; donor disinterest or fatigue; and political choice on the part of the host government at any level (Idachaba, 2004).

Food access is ensured when households and all individuals within them have adequate incomes or other resource to purchase or barter to obtain levels of appropriate foods needed to maintain consumption of an adequate diet/nutrition level (Riley et al., 1995). Access depends upon income available to the household, on the distribution of income within the household and on the price of food. Constraints to individual food access include; economic growth that is inadequate in aggregate, insufficiently broad-based, in general, leading to a lack of job opportunities or lack of incentives to become a productive participant in the economy; negative impacts of national economic policies; inadequate training and job skills; lack of credit or other means to exchange assets or income steams; and food loses associated with inefficient and ineffective harvesting, storage, processing, and handling; political decision favouring one group over another (Wibberley, 2005).

Food utilization/consumption is the proper biological use of food, requiring a diet providing sufficient energy and essential nutrients, potable water, and adequate sanitation. Effective food utilization depends in large measure on knowledge within the household of food storage and processing techniques, basic principles of nutrition and proper child care. Constraints to food utilization include: nutrient losses associated with food preparation; inadequate knowledge and practice of health techniques, including those related to nutrition, child care, and sanitation; and cultural practices that limit consumption of a nutritionally adequate diet by certain groups or family members (FAO, 2002). In the 1996 Rome Declaration on World Food Security, food security is defined as; food that is available at all times to which all persons have means of access that is nutritionally adequate in terms of quantity, quality and variety, and is acceptable within the given culture (Madeley, 2002). The Food and Agriculture Organization of the United Nation (FAO) defines food security as a state of affairs where all people at all times, have access to safe and nutritious food to maintain a healthy and active life (FAO, 1997). This means that in order to enjoy food security, there must be on the one hand, a provision of safe, nutritious, and quantitatively and qualitatively adequate food and ,on other hand, rich and poor, male and female, old and young must have access to it.

Food security has been treated as a broader aspect of global poverty, reflected in insufficient income to procure foods available in the global market. (UNDP, 2010) posits that food security is identified by lack of access 
to formal education, sustained cooperative endeavours; balanced family household; appropriately addressed gender and family roles; rampant poverty: appropriate social, political and economic discrimination; longer life expectance, enabling values and attitudes; distribution of wealth . He concludes that, "societies with low levels of social organization and weak systems of human capital formation have high levels of food insecurity". Successful food security and poverty-oriented programmes did not only assist poor rural population to produce more and diversified products, but to produce a surplus that can be marketed and thereby generate income for the purposes of improving quality of life through improved diet and nutrition investment in productive activities; and as collateral for credit to purchase inputs or other supplies to enhance agricultural or non-agricultural enterprise.

\section{Food Security Framework}

According to the USAID policy paper entitled "Food aid and food security" (1999), to range of important issues, which lead to the food insecurity of households and individuals in the developing world, Nigeria inclusive, are among others: chronic poverty, rapid population growth, declining per capita food output, poor infrastructure, ecological constraint, limited arable land, inappropriate policies, disease, poor water sanitation, inadequate nutritional knowledge, civil war and ethnic conflicts. The complexity of the food security problem in developing countries suggests the need to develop a framework, which leads to a consistent analysis of the actual mechanisms that undermine the food security of specific population groups. Food security framework highlighted by USAID in 2010, was pointed in three dimensions ways namely; (a) availability, (b) access, (c) utilization, and nature of their relationship to one another, as well as a brief description of their determinants. Food availability is a function of the combination of domestic food stocks, commercial food imports, food aid and domestic food production as well as the underlying determinants of each of these factors. Use of the term availability is often confusing, since it can refer to food supplies available at both the household level and at a more aggregate (regional and national) level. However, the term is applied most commonly in reference to food supplies at the regional or national level.

Food access is influenced by the aggregate availability of food through the latter's impact on supplies in the market and, therefore, on market prices. This is further determining by the ability of households to obtain food from their own production and stocks, from the market, and from other sources. These factors are in turn, determined by the resource endowment of the household which defines the set of productive activities they can pursue in meeting their income and food security objectives (Aneke, 2007). Food access is also a function of physical environment, social environment and policy environment, which determine how effectively households are able to utilize their resources to meet their food security objectives. Drastic changes in these conditions, such as during periods of drought or social conflict, may seriously disrupt production strategies and threaten the food access of affected households. These shocks often lead to the loss of productive assets such as livestock, which have severe implications for the future productive potential of households and, therefore, their long-term food security (Oni et al., 2009)

Food utilization, which is typically reflected in the nutritional status of an individual, is determined by the quantity and quality of dietary intake, general child care and feeding practices, along with health status and its determinants. In any given context, food security concerns may be due to either inadequate physical availability of food supplies, poor access among a specific segment of the population, or inadequate utilization. The conceptual frameworks are in hierarchy of causal factors which ultimately influence the various dimension of food insecurity (Omonona \& Agoi, 2007).

\section{Monitoring and Evaluation System of Food Security in Nigeria}

Fairly standard and useful breakdown of the monitoring and evaluation system of food security for understanding the various elements of food security intervention programmes: Programme inputs refer to the set of resources, physical facilities, equipment's, and operational policies that enable programme services to be delivered. In the NSPFS programme, the inputs include ADP staff, facilities (Oni et al., 2009). Programme processes refer to the set of activities, or functional areas, through which programme inputs are used to obtain the expected results of the programme. These processes can be broken down according to special function areas, which are fairly generic in their application across programme types, including management, supervision of various components of the programme, counterpart training, logistics, and service delivery, as well as information systems (Aneke, 2007).

Programme outputs refer to the results of programme activities at the programme level, regarding the quality and quantity of goods and services delivered under the programme. Programme outputs may refer to: Specific functional area activities, such as the number of supervisory visit completed the number of health or extension staff trained, or the quantity of food delivered to a warehouse. Service outputs, related to the access to and quality of the services provided, such as ability to increase the number of programme locations, the average distance to service delivery points, assessments of the knowledge and practice of service providers and other measures of service quantity and quality. The degree of service utilization by programme beneficiaries, which always including; the number of people given loan, percentage of households adopting a recommended agricultural technology package (Idachaba, 2004). Programme impact or performance refer to the set of results, such as changes in access 
to and quality of resources, changes in behaviour, improvements in well-being that occur at the beneficiary level and that can be directly attributed to programme activities and outputs. While basic food security conditions may improve over the life of the intervention, perhaps as a result of external process, it is the attribution of some elements of those changes to programme activities that constitutes the basis of the term impact in monitoring and evaluation ground (Oni et al., 2009).

Programme impacts can be further broken down to distinguish: Performance on capability, which is referred to as intermediate-level programme outcomes; this include improvements in the access to, or quality of resources, and improvements in the knowledge and practices of beneficiaries. These intermediate performances provide beneficiaries with the necessary tools to bring about sustainable improvements in their own food security status and general well-being (Aneke, 2007). Increases in irrigated area resulting from NSPFS, improved access to working capital as part of micro-enterprise development activities, as well as the improved knowledge and change in behaviour of farmers, which can result from education and training efforts are examples of programme performance which influencing beneficiary capabilities, the performance on well-being, which refers to the final programme result at the beneficiary level that are directly related to their food security status and well-being (Okereke, 2012).

The impacts of emergency feeding programmes may be measured in terms of their influence on the consumption levels of intended beneficiaries, whereas the impacts of agricultural programmes may best be measured in terms of changes in crop yields, food production, and incomes. For health and nutrition-related programmes, impacts on well-being may best be expressed by improvements in nutritional status, as well as reduced morbidity, mortality and fertility. In any monitoring and evaluation system, it will be necessary to identify and monitor indicators that represent key inputs, process and outputs in addition to impacts. The ability of programmes to effectively transform inputs into output will determine the effectiveness of the programme in terms of its impacts at the beneficiary level (IFPRI, 2004). Without knowing who received what quantity and quality of services and at what cost, it is difficult to interpret the results of impact evaluations in a way that directly support decision-making. Indicators of inputs and outputs are typically derived from the routine monitoring of programmebased data and reflect the efficiency of the programme performance. In contrast, impact indicators are typically derived from information at the beneficiary-level (i.e from participating households or individuals) (Wibberley, 2005).

\section{Statement of the Problem}

National Special Programme for Food Security was designed to be implemented in phases. It began to work with group of farmers on a pilot scale at few selected sites in each participating country with the intention that, the piloting should then be progressively extended to all major agro-ecological regions. The programme was scaledup to attain full national coverage, giving particular attention to policy and institutional reforms which would address constraints and create a supportive environment for the expansion of small- scale farmers output (Special Programme for Food Security (SPFS, 2003).

The Federal Government of Nigeria plans to extend the NSPFS to other areas of the country at the end of the pilot phase in line with one of the Millennium Development Goals (MDGs) which is to eradicate extreme poverty and hunger by halving the proportion of people in Nigeria whose income are very low to come by, thereby reducing the proportion of people who suffer from hunger between 1990 and 2015 (MDGs, 2004). Nigeria is blessed with fertile land (Vision, 2010) but, yet cannot provide enough food for her teeming populace, unless complemented with net food importation (Yusuf, Baba, Mohammed \& Dogondaji, 2009). In the early 60's to mid-80's Nigeria had the ability to meet up with her food requirements. All of a sudden, something went wrong (Oni, Pender, Philips, $\&$ Kato, 2009). Therefore, if there will be sufficient food supply for her citizenry, certain checks must be put in place.

This study aims at examining the benefits of the National Special Programme for Food Security in Niger State. The State plays a vital role as an agrarian State that possesses fertile agricultural land as a cherished asset whose potentials in securing food productions are yet to be fully exploited (Vision, 2010). Based on the foregoing, it can be said that despite the great potential that the State has in resolving food crisis, pockets of the population are still food insecure. Does this mean that the NSPFS programme like the previous programmes has not benefiting as expected?

\section{Objectives of the Study}

The broad objective of this study was to examine the benefits of the National Special Programme for Food Security (NSPFS) in Niger State, Nigeria. The specific objectives of this study will be to:

1. identify the specific benefits of the programme that accrued to the beneficiaries of the programme;

2. determine the food security status of the beneficiaries in the study area. 


\section{Research Questions}

The following two research questions were raised for the study

1. What specific benefits of the programme that accrued to the beneficiaries of the programme?

2. What is the food security status of the beneficiaries in the study area?

\section{Methodology}

This study adopted descriptive research of survey design which comprises of selected farmers in Niger state. Multistage sampling procedure was employed in the selection of respondents for the study. The first stage involved purposive selection of the programme sites in the three agricultural zones in the State namely; Zones I, II, and III. There were nine project sites in the whole State. The second stage involved the selection of L.G.As in the respective project sites. This selection was purposive because, only L.G.As where project sites are domiciled was selected. The third stage involved the purposive selection of farming communities/villages that had benefited from the programme. The field survey indicated that, the State have nine sites which comprise of farming communities/villages that have benefitted from the programme. All the nine sites formed the sampling frame for the purpose of this research work, namely: Nassarawa, Batavovogi, Lenfa-Bororo, Gidan-Mangoro, Garam, Makangara, Lioji, Kaboji, and Shambo. The benefitting communities were purposively selected as follows: From Zone I (with headquarters in Nasarawa), three sites, namely, Nasarawa, Batavovogi and Lenfa-Bororo were selected; while Gidan-Mangoro, Garam and Makangara were purposively selected from Zone II with headquarters at Gidan-Mangoro. From Zone III, (whose headquarters was located in Lioji) the following sites were purposively selected Lioji, Kaboji and Shambo respectively. A total of 180 respondents were selected for the study. The data used for the study were from primary and secondary sources. Data were collected from the respondents using interview schedules (for the non-formal educated farmers) and the questionnaire (for the formal educated farmers) containing both open and close ended questions. The data collected for the study were analyzed using descriptive statistics and t-test for the hypothesis formulated for the study.

\section{Results and Discussion}

Benefits of the Programme

This study found that farmers under the NSPFS benefitted from input supplies. The input supplies include credit facilities, improved agro-seeds and agro-chemicals. The following section attempted to discuss the benefits that accrued to the beneficiaries.

\section{Credit Facility}

Results of access by respondents to credit facilities are presented in Table 1 .

Table 1: Distribution of respondents according to access to credit facilities

\begin{tabular}{lll}
\hline Credit facilities & Frequency & Percentage $(\%)$ \\
\hline No & 64 & 35.56 \\
Yes & 116 & 64.44 \\
\hline Total & 180 & 100.00
\end{tabular}

Source: Field Data, 2013

Results in Table 1 showed that majority i.e (64.44\%) of the respondents had access to credit, while (35.56\%) of the respondents did not have access to credit facilities. A research work undertook by Oyedele and Akintola, (2012) showed that majority $(53.30 \%)$ of the farmers had access to NSPFS credit while $(46.70 \%)$ did not have access to credit under the programme. Their research finding agreed with this research work, which showed that majority of the respondents had access to credit facilities. The implication is that, the respondents will able to expand their farm sizes, hire labour, purchase agro-inputs and have enough capital bases that could improve their livelihoods.

\section{Actual Amount of Credit Facilities Received}

The actual amounts of funds loaned out to respondents are shown in Table 2.

Table 2: Amount received by the respondents from NSPFS

\begin{tabular}{lll}
\hline Amount received (in Naira) & Frequency & Percentage \\
\hline $1-20,000$ & 2 & 1.72 \\
$20,001-40,000$ & 26 & 22.41 \\
$40,001-60,000$ & 49 & 42.24 \\
$60,001-80,000$ & 18 & 15.52 \\
$80,001-100,000$ & 12 & 10.35 \\
$>100,000$ & 9 & 7.76 \\
\hline Total & 116 & 100.00 \\
\hline
\end{tabular}

Source: Field Data, 2013 
Results obtained in Table 2 showed that, $42.24 \%$ of the respondents obtained between $\$ 40,001-\$ 60,000$, $22.41 \%$ received $\$ 20,001-\$ 40,000$, while $15.52 \%$ had access to $\$ 60,000-\$ 80,000$. Results further showed that a total of $10.35 \%$ of the respondents had access to $\$ 80,000-\$ 100,000$ and lastly $7.76 \%$ of the farmers in the study area had access to greater than 100,000. This implies that loans made available to respondents were of small nature. The loans were meant to enable respondents acquire production inputs. This research work also corroborated the findings of Adebayo, (2010) who found that $35.00 \%$ of the beneficiaries affirmed that the credit given to them was too small, while $31.67 \%$ of the beneficiaries opined the interest rate charged was too high, $15.00 \%$ of the beneficiaries complained that the payback period was too short, $13.33 \%$ said it was time consuming to obtain the credit, while $5 \%$ of the beneficiaries said the credit facility met them in a wrong time. Smallness of loan could constrain or impede growth and expansion of enterprise.

\section{Credit Facilities in Kind during the Cropping Season}

The credit facilities in kind are given to the farmers to encourage them to produce more across the various components.

Table 3: Credit facilities in kind during the cropping season

\begin{tabular}{lll}
\hline Materials in kind & Frequency & $\%$ \\
\hline Stem cutting & 43 & 23.89 \\
Agro-chemical & 81 & 45.00 \\
Good seeds & 65 & 36.11 \\
Good seedlings & 34 & 18.89 \\
Other materials & 2 & 1.11 \\
\hline
\end{tabular}

Source: Field Data, 2013

Results in Table 3 indicated that agro-chemicals ranked the highest in terms of material supplied in kind with (45.00\%) followed by good seeds (36.11\%) and stem cuttings $(23.89 \%)$, and a total of (18.89\%) received good seedling, $(1.11 \%)$ other materials. The implication is that, it helps the respondents to augment their meager resources given that they experience paucity of resources which compel them to over rely on household resources.

\section{Agro-enterprises Introduced}

The NSPFS also introduced agro-enterprises in the project sites. These are summarized in Table 4.

Table 4: Agro-enterprises introduced by NSPFS

\begin{tabular}{lll}
\hline Agro-enterprises & Frequency $*$ & Percentage $(\%)$ \\
\hline Agro-forestry community orchard & 156 & 86.67 \\
Woodlot & 8 & 4.44 \\
Agro-forestry nursery & 62 & 34.44 \\
Fishery & 46 & 25.56 \\
Livestock fattening & 154 & 85.56 \\
\hline
\end{tabular}

Source: Field Data, 2013

Note: * implies multiple responses were recorded.

Results in Table 4 indicated that a greater proportion, i.e $86.67 \%$ of the farmers benefitted from agro-forestry community orchards, while $13.33 \%$ did not benefitted. A total of $85.56 \%$ directly benefitted from livestock fattening, while $14.44 \%$ of the farmers did not participate in rearing farm animals, $34.44 \%$ of the farmers obtained direct agro-forestry community nurseries, while larger proportion $(65.56 \%)$ of the sampled farmers were not involved in agro-forestry community nurseries, $25.56 \%$ of the respondents benefitted from fishery, whereas, $74.44 \%$ of the farmers did not participate in fishery production, one could presume may be due to inadequate water in their domain, $4.44 \%$ of the respondents were able to benefit from the programme by obtaining direct woodlot from the programme, meanwhile, $95.56 \%$ were not able to have access. Agro-enterprises help to empower the farmers, and this enabled farmers to augment their incomes to meet their basic needs. It is a diversification strategy adopted by the farmers. In addition, the benefitting farmers were also engaged in livestock fattening enterprises as it improved their livelihoods and also created room to serve as a source of dietary protein. 
Agro-inputs benefitted from N.S.P.F.S by Farmers

Table 5: Agro-inputs benefitted from N.S.P.F.S in Niger State

\begin{tabular}{llll}
\hline \multicolumn{1}{c}{ Agro-input support } & Frequency* & Percentage & Ranking \\
\hline (a) Agro-inputs support & 85 & 47.22 & 1 \\
(b) Storage facilities & 38 & 21.11 & 5 \\
(c) Mechanization services & 39 & 21.67 & 4 \\
(d) Extension and financial services & 83 & 46.11 & 2 \\
(e) Agro-enterprises development & 4 & 27.22 & 3 \\
(f) Small scale irrigation & 1 & 0.56 & 9 \\
(g) Processing machines & 25 & 13.89 & 6 \\
(h) Infrastructure & 2 & 1.11 & 8 \\
(i) Marketing/storage & 10 & 5.56 & 7 \\
\hline
\end{tabular}

Source: Field Data, 2013

*Multiple responses were recorded.

The agro-inputs benefitted were summarized in Table 5. Results in Table 5 showed that, $47.22 \%$ of the participating farmers obtained agro-inputs support and such agro-inputs support include fertilizers, herbicides, improved maize seeds, knapsack sprayers etc. Also, other incentives given to them include storage facilities such as; iron silos, storage bins, and concealed containers. A total of $21.11 \%$ of the total sampled farmers benefitted from storage facilities.

Furthermore, $21.67 \%$ of the total respondents benefitted from mechanization services rendered. The mechanization services rendered include boreholes, sprayers, and farm machines e.g tractor services. In like manner, the programme equally rendered extension and financial services to the farmers sampled in the three agricultural zones, $46.11 \%$ of the farmers benefitted from it, while, $53.89 \%$ did not.

Results further revealed that $27.22 \%$ of the farmers benefitted from agro-enterprise development. Also, only a very small proportion $(0.59 \%)$ of sampled respondents benefitted from small scale irrigation such as; surface and channel irrigation. The study also showed that, rice, groundnut and cassava processing machines were introduced to the farmers to help them in farm produce processing. About $13.89 \%$ of them benefitted from it. Only $1.11 \%$ benefitted from infrastructures and $5.56 \%$ of the respondents benefitted from farm marketing/storage facilities programme. This implies that lacks of storage facilities have been implicated to be responsible for post-harvest losses.

\section{Test of Hypothesis}

Ho: There is no significant difference in the crop output of beneficiaries and non- beneficiaries respondents Table 6: $t$-test showing the difference between crop output of the beneficiaries and non-beneficiaries

\begin{tabular}{lccccc}
\hline Variables & Means & t-value & Df & P-value & Decision \\
\hline Beneficiaries & 66431.56250 & $4.5880^{* * *}$ & 63 & 0.0000 & Hypothesis \\
Vs & & & or P $<$ & rejected \\
Non-beneficiaries & & & 0.01 & \\
\hline
\end{tabular}

Source: Field Data Analysis, (2013)

Results in Table 6 indicated that the computed t-value was 4.5880 which was greater than the critical t-value of 1.658 at 0.05 probability level and 63 degrees of freedom. The null hypothesis is hereby rejected. The implication is that, the outputs obtained by the two groups of the farmers were different because the beneficiaries had access to production inputs such as fertilizers, agrochemicals, credit facilities among others which increased their productivity.

\section{Conclusion and Recommendations}

The study concludes that the beneficiaries were satisfied with the implementation of the following components: agro-input support, extension and financial services. NSPFS significantly improved the crop output of beneficiaries as compared to non-beneficiaries. The benefits that accrued to the beneficiaries of the programme ranges from credit grant to farmers to provision of storage facilities, which translated into increased outputs. The following recommendations were made based on the major findings of the study. The NSPFS should focus more attention on mechanization, storage facilities, agro-processing, marketing, small scale irrigation, and infrastructure, because it will help the benefitting famers to actualize their pre-determined goals, it will also improve their wellbeing.

\section{References}

Adebayo, C. O. (2010). Evaluation of United Nations Development Programmes (UNDP) Micro Credit Scheme on Food Security Status of Farm Households in Kaduna State. Unpublished Ph.D Dissertation, Ahmadu Bello 
University, Zaria, Nigeria.

Ajayi, A.R. (2000). An ex-post evaluation of the performance indices of the Ekiti-Akoko enclave Agricultural Development Programme, Ondo State, Nigeria. Application for Tropical Agriculture, 5 (1): 48-56.

Aneke, M.O (2007). Impact of the Phase- 1 National Special Programme on Food Security on Poverty Reduction in Enugu State, Nigeria, A M.sc Thesis, Published edition. University of Nigeria, Research Publications, Innovation Centre, Dated 9th May, 2009.

Dauda, S. and Ajayi, A.R, (2009). Assessment of the Performance of the National Special Food Security Programme in Benue State, Nigeria. Journal social for sciences, 21 (1): 25-32

Dougherty, C. (2007): Introduction to Econometrics. Oxford University Press ISBN, 194.

FAO, (1997). Guide for the conduct of the constraints analysis component. Special Programme for food Security; Handbook series, SPFS/DOC/18. Rome.

FAO, (2002). The State of Food Insecurity in the World 2001, Rome, April 2002

Food and Agriculture Organization of the United Nations. (1996). Declaration on World Food Security. World Food Summit. Rome, Italy. Retrieved June 14, 2014, from: www.fao.org/docrep/003/w3613e/w3613e00.htm.

Idachaba F.S. (2004). Food security in Nigeria: challenges under democratic dispensation, $9^{\text {th }}$ ARMTI annual lecture, Ilorin, 24th March, 2004

IFPRI., 2009. 2009 global hunger index: Key facts and findings. International Food Policy Research Institute, Addis Ababa, Ethiopia. http://www.ifpri.org/sites/default/files/p ublications/ghi09keyfacts.pdf.

Madeley, J. (2002). Food for all: The need for a new agriculture, 2002, pp. 34. In Clover, J. Food Security in SubSaharan Africa; African Security Review 12 (1), 2003.

Maxwell, S \& Smith, M. (1992). Household Food Security; A conceptual review. In S. Maxwell and T. R Frankenberger, eds. Household Food Security: Concepts, Measurement: A Technical Review New York and Rome: United Nation International Children Educational Fund and International Fund Agricultural Development.

Maxwell, S. (1996). Food Security: A post- modern perspective on food policy. 21 (2): 155-170.

Maziya-Dixton, B; Akinyele, I.O; Oguntona, E.B; Nokoe, S; Sanusi, R.A and Harris, E. (2004). Nigeria Food Consumption and Nutritional Survey 2001-2002. Summary International Institute for Tropical Agriculture.

Mero, A. N (2001). Extension and Training Activities under the Special Programme for Food Security in the United Republic of Tanzania. Human Resource In Agricultural Development, 2: 49- 56.

Nworgu, F. C. (2006). Prospects and Pitfall of Agricultural Production in Nigeria. Ibadan, Blessed Publication Consultants/Publication.

Okereke, C.O. (2012).Challenges of Risk Management among Smallholder Farmers in Ebonyi State, Nigeria: Implications for National Food Security, International Journal of Agricultural Economics \& Rural Development. 5 (1), 18-27

Omonona, B.T and Agoi G.A (2007). "An analysis of food security situation among Nigeria Urban Households: evidence fromLagos State, Nigeria” Journal of Central European Agriculture, 8 (3): 397-406.

Oni, O., Pender,J., Philips,D. and Kato, E. (2009). Trends and Divers of Agricultural Productivity in Nigeria. Nigeria Strategy Support Programme (NSSP) Report 001:IFPRI.

Overseas Development Institute, (1997). Global Hunger and Food Security after the World Food Summit, briefing Paper 1997 (1) February, London.

Oyedele, G. A. and Akintola, J. O (2012). Determinants of access to credit in Nigerian agriculture, Journal of Development and Agricultural Economics Vol. 4(10), pp. 275-286, June, 2012 Available online athttp://www.academicjournals.org/JDAE

Riley, F., Mock, N., Cogill, B., Bailey, L. \& Kenefick, E. (1995). Food Security Indicators and Framework for use in the monitoring and evaluation of food aid programme. IMPACT: Food Security and nutrition, monitoring project. Arlington, Va., United State of America Sector, Abuja.

Sengooba, T. (1994). Root Crops for Food Security in Africa. In. Akorede M.O (ed.). Proceeding of the 5th Triennial Symposium of International Society of Tropical Root, Kampala, Uganda pp 23-25.

SPFS, (2003). Nigeria’s SPFS http:www.niger iafirst.org/article4461.shtml.January2003.

United Nation Development Programme, (2010). What Will It Take to Achieve the Millennium Development Goals? An International Assessment, June 2010.

USAID Report (2010). www.fews.net/Nigeria Nigeria Food Security Update and Development December, 2000 37 (4).

USAID, (1999). Policy Paper entitled "Food aid and Food Security". http://www.usaid.gov2000.

Vision, (2010). Agriculture, 1997: Final Report of the Sub-Committee on Agriculture Economic

Wibberley, E. J. (2005). Oil and Agriculture: Frameworks and Farmers for Food Security. Paper Presented at animal lecture organized by the centre for food agricultural Strategy, University of Agriculture, Makurdi, March 22, 2005.

WHO, (2004). Millennium Development Goals Report, Abuja:FGN/WHO. 
Yusuf, B. I; Baba, K.M, Mohammed, I. and Dogondaji, S.D. (2009). "Determinants of rice Production: A guide for food security policy in Nigeria."In "sustaining Agricultural Growth to meet national economic development goal."Proceedings of the $23^{\text {rd }}$ Annual Conference of the Farm Management Association of Nigeria, FAMAN. 